\section{Row over vaccine trial}

\section{Washington}

THE Argentine ministry of public health is claiming that animal handlers who cared for cows inoculated with a recombinant vaccinia-rabies vaccine have developed antibodies to rabies, suggesting that the virus was shed from the inoculated animals and infected their handlers.

The Argentine government has indicated that it intends to take legal action for redress of damages caused by the way the trial was conducted until it was halted on their instructions.

The experimental vaccine, developed by the Wistar Institute of Philadelphia, Pennsylvania, was being tested by the Pan American Health Organization at its experimental farm in Azul in the province of Buenos Aires. The trial began in July 1986, when 20 cows were inoculated with the virus. The cows were housed with 20 non-inoculated control animals to see if the virus would spread to the controls. But the Argentine government stopped the trial in September, claiming it had not been informed that the trial involved the release of a recombinant vaccine (see Nature 324, $202 \& 610 ; 1986)$. The cows were still allowed to roam through pens enclosed only by barbed wire. The government says that milk from the inoculated cows was sold to local dairies. All 40 animals were killed in November.

According to a ministry of public health report, serum samples from the control animals taken before they were killed indicated the presence of rabies antibodies which had not been present before the experiment. In addition, "some" of the 17 people who had varying degrees of exposure to the inoculated animals developed antibodies to rabies. None of the people has developed health problems, but they will be monitored. A spokeswoman for the Argentine embassy could not say what damages the Argentine government will seek, nor who will be sued.

The Pan American Health Organization has no comment on Argentine claims, saying it is still discussing the case with the Argentine government. Warren Cheston, of the Wistar Institute, says the discovery of rabies antibodies in the animal handlers and control animals is a surprise if it is confirmed. He says serum samples from the control animals available to Wistar researchers taken 3 months after the inoculations did not indicate the presence of rabies antibodies. None of the people exposed to similarly vaccinated animals at the Wistar Institute has ever developed an increased rabies antibody titre. Cheston says a final verdict on the Argentine claims will have to wait until a full release of experimental data is made. Joseph Palca

\title{
AIDS brochure mailing will go ahead in United States
}

\section{Washington}

Despite a false start last autumn, plans appear on track to mail a brochure containing information on AIDS to every household in the United States. Officials from the US Department of Health and Human Services announced at an international summit of health ministers in London last month that the brochure will be mailed in June or July.

The brochure was supposed to have been mailed last October, as part of the "AIDS Prevention Month" declared by the US Centers for Disease Control (CDC), but political squabbles broke out over the content of the brochure, and which agency should be responsible for it. Although a draft brochure was said to be in the last stages of production, deliberation on the proposed mailing was mysteriously dropped from the agenda of the first public meeting of the presidential commission on the AIDS epidemic. A brochure entitled What You Should Know About AIDS was released by the CDC instead, but distribution was limited to local health departments, hospitals and other healthcare practitioners.

The new brochure is being developed by the advertising agency Ogilvy \& Mather, and is currently being tested on 'focus groups' of the general population to determine what revisions are necessary to make it most effective. It is likely to focus on correcting the public's knowledge about the transmission and prevention of AIDS The level of misinformation about the transmission of the AIDS virus is particularly high. According to data gathered by the National Center for Health Statistics, 36 per cent of the population believes that it is very likely that someone receiving a blood transfusion will be infected with the virus. In addition, 36 per cent feel it is possible to be infected with the AIDS virus by eating in a restaurant where the cook has AIDS, and 35 per cent believe they can contract AIDS from mosquitoes.

Carol Ezzell

\section{Moonlighting OK}

\section{London}

SCIENTISTS in Liaoning province in northeastern China are to be allowed to earn at least 50 per cent of their income from spare-time jobs, in an attempt to get them more closely involved with the local economy, the Guangming Daily has reported. The provincial authorities have for years been trying to foster links between scientists and local production, the paper said, but the existing contract scheme of payments "limited" the scientists' enthusiasm. In launching the new scheme, the provincial leaders said that any regulations "not conducive to improving productivity or tapping scientists' talents to the full" would be cancelled.

Vera Rich

\section{AIDS research centre to be set up in India}

\section{New Delhi}

WORRIED about the growing incidence of human immunodeficiency virus (HIV) infection, India has set up a centre dedicated to research on acquired immune deficiency syndrome (AIDS). It will eventually become a fully fledged institute under the Indian Council of Medical Research (ICMR).

The AIDS Research Centre is in Madras, capital of the state of Tamil Nadu, which has most of the $200 \mathrm{HIV}$-positive cases so far identified in India. One new case is detected every week in the state.

Dr Khorshed Pavri, the retiring director of the National Institute of Virology in Pune, has been made project director of the new centre. A nine-member expert committee has been set up to formulate the centre's research projects. ICMR says the centre will coordinate surveillance and epidemiological work and carry out virological and immunological studies "in the entire spectrum of HIV infection". It will also be the only facility in the country for treatment of AIDS victims.
One research project to be taken up by the centre is on the role of the retroviruslike intracisternal A-particle (IAP) recently isolated by Pavri from a prostitute with atypical sero-response to HIV. According to Pavri, the IAP, seen for the first time in humans, could act as a precursor to HIV. Interestingly, studies at the ICMR Institute of Leprosy in Agra have shown antigenic cross-reactivity between HIV and mycobacteria that cause leprosy and tuberculosis.

Some ICMR scientists suggest that Mycobacterium avium intracellulare (MAI) infection, widely present in India, may be protecting Indians against AIDS in the same way that dengue virus infection protects against yellow fever. ICMR is planning further studies to look for common antigenic patterns and gene sequences between HIV and mycobacteria. Meanwhile, Dr M.G. Deo, director of the Cancer Research Institute in Bombay, has suggested that the cross-reactivity can be exploited to develop an AIDS vaccine containing a number of strains of MAI.

K. S. Jayaraman 